\title{
JUURNAL_RU
}

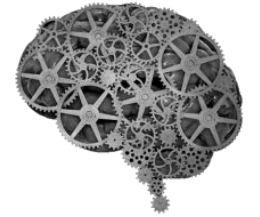

COMPANY GROUP "INTELLEKT"

\author{
Залесская И.А., Залесский А.Ю., Сидельникова Н.Г. \\ МБУЗ Городская больница №1 им.Н.А.Семашко города Ростова-на-Дону \\ Ростов-на-Дону, Россия
}

doi: 10.18411/lj2016-7-1-08

idsp 000001: lj2016-16-1-08

\section{Ретроспективный анализ отогенных внутричерепных осложнений (по материалам ЛОР отделения ГБ№1 г.Ростова-на-Дону)}

Проблема отогенных внутричерепных осложнений (OBO) не только не теряет своей актуальности последние несколько десятилетий, но и остается одной из самых сложных в ЛОР-практике. Значительные успехи в области клинической медицины и медицинской технологии, в частности внедрение в практическое здравоохранение новых антибиотиков, а также УЗИ, КТ, МРТ и др. за последние несколько десятилетий позволило значительно улучшить диагностику отогенных внутричерепных осложнений, однако, это не существенно влияет на частоту встречаемости и уровень летальности.

Несмотря на прогресс в создании новых антибактериальных препаратов и развитие новых способов диагностики, летальность при данном заболевании остается высокой и занимает одно из первых мест, а по данным некоторых авторов I место по летальности в ЛОР патологии. По данным разных авторов она составляет от 25 до $30 \%[2,6]$.

Наряду с достижениями все чаще стали появляться сведения, указывающие на ряд особенностей течения отогенных гнойно-септических осложнений, не свойственные доантибиотиковому периоду: стертость, атипичность, малосимптомность клинических проявлений и связанные с этим трудности в диагностике и дифференциальной диагностике различных 
вариантов отогенных осложнений и, соответственно, несвоевременное оказание больным специализированной врачебной помощи [2].

Многие литературные источники [3,4,5] отмечают увеличение частоты ОВО при острых средних отитах.

В литературе имеется значительное расхождение данных о летальности от ОВО в целом, по частоте встречаемости тех или иных осложнений, а также по преобладанию в этиологии острого или хронического среднего отита.

Так, например, по данным исследований И.А. Волошиной, Р.Б. Харамзиевой [1], ОВО, возникающие на фоне острого воспалительного процесса в среднем ухе, встречаются почти в 2 раза чаще, чем при хроническом гнойном среднем отите.

Противоположные данные приводит С.Я. Косяков (2014 г): в большинстве случаев $(84,6 \%)$ ОВО развиваются на фоне хронического гнойного среднего отита, причем чаще $\mathrm{y}$ больных $\mathrm{c}$ более чем пятилетней историей воспалительного процесса в среднем ухе. Хронический гнойный средний отит у взрослых ассоциируется с абсцессом мозга, а острый средний отит у детей - с эпидуральным абсцессом.

Целью нашего исследования было изучение эпидемиологии OBO в Ростове-на-Дону за период с 1995 по 2015 год. В задачи исследование входило: определить ведущее этиологическое заболевание, особенности клинического течения, лечения и исходы.

Материалы и методы исследования. Мы провели ретроспективный анализ случаев ОВО по архивным материалам ЛОР отделения для взрослых городской больницы № 1 г Ростова-на-Дону, которая оказывает круглосуточную неотложную помощь больным с ЛОР патологией. Изучено 53 истории болезни пациентов и операционные журналы.

В большинстве случаев - ОВО были осложнением острого среднего отита (44 пациента из 53 - 83,1\%).

В структуре осложнений преобладали отогенные менингоэнцефалиты. 


\begin{tabular}{|c|c|}
\hline Менингоэцефалит & 39 \\
\hline Менингит & 11 \\
\hline Абсцесс мозжечка & 1 \\
\hline Экстрадуральный абсцесс & 1 \\
\hline Тромбофлебит сигмовидного синуса и внутренней яремной вены с отогенным \\
сепсисом, экстрадуральный абсцесс & 1 \\
\hline
\end{tabular}

$33,9 \%$ (18 случаев) закончились летальным исходом.

Количество ОВО из года в год оставалось одним и тем же, отмечался единственный подъем - в 2009, летальность варьировала от 0 в 2012 до 100\% в 2013 и 2015 гг. Далее в таблице представлен сравнительный анализ частоты встречаемости ОВО и летальности по годам (выборочно).

\begin{tabular}{|c|c|c|c|c|c|c|c|c|c|c|c|}
\hline & 1995 & 1998 & 2002 & 2005 & 2009 & 2010 & 2011 & 2012 & 2013 & 2014 & 2015 \\
\hline Всего случаев & 3 & 3 & 3 & 4 & 6 & 4 & 1 & 2 & 3 & 2 & 2 \\
\hline Летальность & 2 & 2 & 1 & 1 & 3 & 1 & 1 & 0 & 3 & 1 & 2 \\
\hline
\end{tabular}

Существенных гендерных различий в анализируемой группе пациентов выявлено не было. Что касается возраста больных, определенной связи не отмечалось (он составил от 21 до 82 лет), однако все умершие были старше 37 лет. (37-79).

У всех умерших пациентов имелась сопутствующая патология, иногда сочетанная, среди которой преобладали: гипертоническая болезнь и сахарный диабет (50\% и $38,8 \%$ соответственно).

\begin{tabular}{|c|c|}
\hline Сопутствующая патология & Количество случаев, \% \\
\hline Сахарный диабет, в том числе впервые выявленный & 3 \\
\hline Гипертоническая болезнь & $38,8 \%$ \\
\hline ИБС, атеросклероз & $50 \%$ \\
\hline Хр.гепатит, холецистит, панкреатит, хр.алкоголизм & 4 \\
\hline Цирроз печени & $22,2 \%$ \\
\hline Ожирение & $16,6 \%$ \\
\hline & $5,5 \%$ \\
\hline
\end{tabular}

Сроки обращения пациентов в стационар от начала заболевания варьировали от 2 д дней до 2 недель, при этом $71 \%$ больных обратились к врачу в течение первой неделе заболевания). 
68\% умерших пациентов отмечали боль в ухе не более недели до проявления признаков осложнений, примерно половина из этого числа - на протяжении 2-3 дней, что позволяет говорить о молниеносности процесса.

Всем больным с острым средним отитом при поступлении был произведен парацентез, а затем - расширенная антромастоидотомия (при остром среднем отите) или расширенная общеполостная операция (при хроническом гнойном среднем отите), причем в $82 \%$ случаев операция выполнена в первые сутки и даже часы после поступления.

После проведенной операции все больные находились в реанимационном отделении (от 1 до 18 суток). Большинство из них находилось на продленной ивл (от 1 до 17 суток).

В реанимационном отделении все больные получали массивную антибактериальную, дезинтоксикационную, противоотечную терапию.

Спектр антибактериальных препаратов, назначаемых в нашей клинике, в разные годы менялся. Так с 1995 - 1998гг в антибиотикотерапии преобладали пенициллин(12-30 млн.ЕД в сутки) и гентамицин. В дальнейшем в лечении ОВО стали использовать комбинацию антибиотика цефалоспориного ряда (цефотаксим, цефоперазон, цефсон, цефтриаксон, сульмовер), с фторхинолонами, или аминогликозидами, или ванкомицином, а с 2008 года все больные получали карбапенемы (меронем до 6 г/сутки).

Проанализировав вышеперечисленное, мы сделали следующие выводы:

1. Количество ОВО за последние 20 лет не имеет тенденции к росту.

2. В этиологии отогенных внутричерепных осложнений в нашей клинике преобладали острые средние отиты.

3. Ранее оказание помощи (хирургическое вмешательство в 1е часы поступления больного с ОВО) не всегда гарантирует положительный исход.

4. У большинства больных с $\mathrm{OBO}$ имеется сопутствующая соматическая патология. 
Летальность при ОВО остается высокой, в среднем - 33,9\%, а в некоторые годы достигает 100\%.

\section{Литература:}

1. Волошина И.А., Хамзалиева Р.Б. Частота летальности при ото- и риногенных внутричерепных осложнениях.// Вестн. оторинолар. 2009. № 1. -C. 23-25.

2. Гаджимирзаев Г.А. $\mathrm{O}$ нерешенных вопросах проблемы гнойносептических осложнений ушного происхождения.// Вестн. оторинолар. 2000. № 6. C. 47-50

3. Дискаленко В.В., Никитин К.А. Отогенные и риногенные внутричерепные осложнения. Пособие. Изд-во СПбГМУ 2002.

4. Косяков С.Я., Носуля Е.В., Перич Б. Основные направления в лечении отогенных внутричерепных осложнений. Вестник оториноларинго-логии. 2014. № 1. С. 64-69.

5. Семак Л.И. Осложнения острого гнойного среднего отита: особенности клиники, диагностики, лечения. Автореф. на соиск. уч. степени канд. мед наук. Минск, 2015

6. Чумаков Ф.И., Селин В.Н., Голубовский Г.А. Новости оторинолар и логопатол 2002. № 4. С. 48-50.

7. Клинические особенности отогенных внутричерепных осложнений на современной этапе. Янов Ю.К., Кривопалов А.А. Вестник оторинолар.2015. №5. С23-29 